\title{
Review
}

\section{Barnyard millet - a potential food and feed crop of future}

Salej Sood ${ }^{1,4}$, Rajesh K. Khulbe ${ }^{1}$, Arun K. Gupta ${ }^{2}, \mathrm{Panan}_{\mathrm{n}} \mathrm{K}$. Agranal ${ }^{1}$, Hari D. Upadhaya ${ }^{3}$ and J A G D ISH C. BHATT ${ }^{1}$

${ }^{1}$ Indian Council of Agricultural Research-Vivekananda Institute of Hill Agriculture, Almora, Uttarakhand 263601 , India; ${ }^{2}$ Indian Council of Agricultural Research-Indian Institute of Wheat and Barley Research, Karnal, Haryana 132001, India; ${ }^{3}$ International Crop Research Institute for the Semi-Arid Tropics (ICRISAT), Patancheru, 502 324, Telangana, India; ${ }^{4}$ Corresponding author. E-mail: salej1plp@gmail.com

With 4 figures and 2 tables

Received May 28, 2014 / Accepted November 12, 2014

Communicated by M. Prasad

\begin{abstract}
The two species under genus Echinochloa, E. frumentacea (Indian barnyard millet) and E. esculenta (Japanese barnyard millet), are cultivated for food and fodder by hilly and tribal communities in Asia particularly in India, China and Japan. The crop has wide adaptability and occupies a special place in marginal rainfed areas because of its short life cycle. Although the area under the crop has come down drastically in last 50 years, the crop ability to survive under harsh conditions makes it a better choice during famine years. In the Indian Himalayan region, the crop was traditionally used as a substitute for rice. It has been identified as a suitable choice for climate-resilient agriculture. High nutrient content and antioxidant effects make it to be considered as a functional food crop. Recently, the demand of the crop has increased due to its highly nutritious grains. Thus, it has the potential to provide both food and nutritional security particularly in hills where nutritional deficiencies are in abundance. Despite enormous potential, the crop has not gained the popularity among masses and is still considered as poor man's food. This work therefore is an attempt to compile the meagre information available on crop history, evolution, crop breeding and present status to make the crop competitive and revamp its cultivation.
\end{abstract}

Key words: breeding — domestication - Echinochloa germplasm - genomic resources — nutritional value — origin - postharvest processing

The genus Echinochloa belongs to the tribe Paniceae, subfamily Panicoideae of the family Poaceae (Clayton and Renvoize 2006). Barnyard millet (Echinochloa sp.) is one of the oldest domesticated millets in the semi-arid tropics of Asia and Africa. Of around 35 species (Table 1), two main species, E. esculenta (A. Braun) H. Scholz; syn. E. utilis Ohwi et Yabuno (Japanese barnyard millet) and E. frumentacea Link; syn. E. colona var frumentacea (Link) Ridl. (Indian barnyard millet), are cultivated as minor cereals in Japan, Korea, the north-eastern parts of China and India, Pakistan and Nepal, respectively (Yabuno 1987) (Fig. 1). Besides these two species viz., allohexaploid E. crus-galli, Lijiang millet and allotetraploid E. oryzicola, Mosou barnyard millet are under cultivation in China (Yabuno 1966, Yuichiro et al. 1999, Yamaguchi et al. 2005).

Barnyard millet is grown for human consumption as well as fodder. It is generally cultivated in areas where climatic and edaphic conditions are unsuitable for rice cultivation (Yabuno 1987). In India, barnyard millet is the second important small millet after finger millet having production and productivity 87 thousand tonnes and $857 \mathrm{~kg} / \mathrm{ha}$, respectively (Padulosi et al.
2009). In India, it is mainly cultivated in two different agro-ecologies, one in mid hills of Himalayan region of Uttarakhand in the North and another in Deccan plateau region of Tamil Nadu in the south. Wild barnyard millet (Echinochloa colona) is commonly found in rice fields as weed and consumed as food during drought years in many states of India (Padulosi et al. 2009).

Owing to fast growth and early maturity, barnyard millet has attracted some attention as a fodder in the United States and Japan and can produce as many as eight harvests per year (http://www.fao.org/docrep/T0818E/T0818E01.htm). The crop straw is considered superior fodder to rice, oat or Timothy straw in protein and calcium content (Obara 1936). Its grains are also used as a major feed for waterfowl and other birds in United States (Mitchell 1989).

\section{History, Origin and Domestication}

Echinochloa frumentacea showed parallel line of evolution both in India and Africa. It is an annual cultivated in India, Central African Republic, Tanzania and Malawi (Doggett 1989). Its wild progenitor is the tropical grass E. colona (L.) Link, popularly known as Jungle rice, but the exact date of domestication is uncertain. Echinochloa esculenta is annual in habit and is cultivated mostly in the temperate regions (De Wet et al. 1983) of Japan, Korea, China, Russia and Germany. Its wild ancestor is barnyard grass (E. crus-galli (L.) Beauv.) from which it was directly domesticated some 4000 years ago in Japan (Doggett 1989).

Archaeological evidence suggests that it was grown in Japan as early as Yayoi period, dating back some 4-5 millennia (Watanabe 1970). Another study puts the earliest records of domestication from Jomon period of Japan in 2000 B.C. (Nesbitt 2005). Nozawa et al. (2004) showed that E. esculenta was domesticated from a limited part of the E. crus-galli population. They used 13 SSR markers to study the genetic diversity of 170 Echinochloa accessions and grouped E. esculenta accessions into two classes, while ancestral species E. crus-galli was grouped into 11 classes.

The domestication syndrome, which refers to all modifications occurring in a crop plant during the course of evolution when it becomes cultivated from the wild form and is dependent on selection pressure (Hammer 1984, 2003), is not well studied in barnyard millet although both E. frumentacea and E. esculenta showed marked difference from their respective wild ancestors E. colona and E. crus-galli with respect to reduced vegetative 
Table 1: Echinochloa species along with their areas of adaptation

\begin{tabular}{|c|c|c|c|}
\hline S1 No. & Species & Synonyms & Areas of geographical presence \\
\hline 1 & Echinochloa brevipedicellata & & Eastern Tropical Africa - Tanzania \\
\hline 2 & Echinochloa callopus & & $\begin{array}{l}\text { Senegal, Mali, Ghana, Nigeria, Sudan, Congo, } \\
\text { Tanzania }\end{array}$ \\
\hline 3 & Echinochloa chacoensis & & Bolivia to North Argentina \\
\hline 4 & Echinochloa colona & $\begin{array}{l}\text { Echinochloa divaricata; Echinochloa equitans; } \\
\text { Echinochloa subverticillata; Echinochloa zonalis }\end{array}$ & Tropical and subtropical old world \\
\hline 5 & Echinochloa crus-galli & $\begin{array}{l}\text { Echinochloa caudata; Echinochloa commutata; } \\
\text { Echinochloa crus-corvi; Echinochloa disticha; } \\
\text { Echinochloa dubia; Echinochloa echinata; } \\
\text { Echinochloa formosensis; Echinochloa glabrescens; } \\
\text { Echinochloa hispida; Echinochloa macrocarpa var. } \\
\text { aristata } \\
\text { Echinochloa macrocarpa var. mutica } \\
\text { Echinochloa macrocorvi; Echinochloa } \\
\text { madagascariensis; Echinochloa micans; Echinochloa } \\
\text { occidentalis; Echinochloa paracorvi; Echinochloa } \\
\text { persistentia; Echinochloa spiralis; Echinochloa } \\
\text { tzvelevii; Echinochloa zelayensis; Echinochloa } \\
\text { zenkowskii }\end{array}$ & $\begin{array}{l}\text { South and East Europe to Asia, West, East and } \\
\text { South Tropical Africa to South Africa, } \\
\text { Madagascar }\end{array}$ \\
\hline 6 & Echinochloa cruspavonis & $\begin{array}{l}\text { Echinochloa aristata; Echinochloa composite; } \\
\text { Echinochloa kimayalaensis; Echinochloa sabulicola }\end{array}$ & $\begin{array}{l}\text { Tropical and South Africa, Assam to South } \\
\text { China } \\
\text { and Indo-China }\end{array}$ \\
\hline 7 & Echinochloa telmatophila & Echinochloa dietrichiana & Queensland, Australia \\
\hline 8 & Echinochloa elliptica & & $\begin{array}{l}\text { Queensland, Northern territory, Western } \\
\text { Australia }\end{array}$ \\
\hline 9 & Echinochloa esculenta & $\begin{array}{l}\text { Echinochloa frumentacea var. atherachne; } \\
\text { Echinochloa frumentacea subsp. Utilis; Echinochloa } \\
\text { utilis }\end{array}$ & Russian far east to Japan \\
\hline 10 & Echinochloa frumentacea & $\begin{array}{l}\text { Echinochloa glabrescens var. barbata; Echinochloa } \\
\text { glabrescens var. glabra; Echinochloa glabrescens } \\
\text { var. pilosa }\end{array}$ & Cultigen from India \\
\hline 11 & Echinochloa haploclada & $\begin{array}{l}\text { Echinochloa aristifera; Echinochloa haploclada } \\
\text { var. stenostachya }\end{array}$ & Africa-Ethiopia to Swaziland \\
\hline 12 & Echinochloa helodes & & Argentina \\
\hline 13 & Echinochloa holciformis & & Mexico, Guatemala \\
\hline 14 & Echinochloa inundata & & $\begin{array}{l}\text { South Australia, Queensland and New South } \\
\text { Wales }\end{array}$ \\
\hline 15 & Echinochloa jaliscana & & Mexico \\
\hline 16 & Echinochloa jubata & & Southern countries of Africa \\
\hline 17 & Echinochloa kimberleyensis & & $\begin{array}{l}\text { Western Australia, Northern Territory and } \\
\text { Queensland }\end{array}$ \\
\hline 18 & Echinochloa lacunaria & & South Australia, New South Wales \\
\hline 19 & Echinochloa macrandra & & Western Australia \\
\hline 20 & Echinochloa muricata & $\begin{array}{l}\text { Echinochloa microstachya; Echinochloa pungens; } \\
\text { Echinochloa wiegandii }\end{array}$ & Canada, USA \\
\hline
\end{tabular}

Senegal, North Nigeria to Sudan

Arizona, Mexico, Guatemala

Echinochloa oplismenoides

Echinochloa oryzoides

Echinochloa coarctata; Echinochloa erecta;

Echinochloa hispidula; Echinochloa macrocarpa;

Caucasus to Japan and Phillipines

Echinochloa oryzicola; Echinochloa pachychloa;

Echinochloa phyllopogon; Echinochloa

phylloryzoides

Echinochloa paludigena

Echinochloa picta

Echinochloa pithopus

Echinochloa polystachya

Echinochloa praestans

Echinochloa spectabilis

Echinochloa frumentacea var. violacea; Echinochloa guadeloupensis; Echinochloa holubii; Echinochloa kimpokoensis; Echinochloa quadrifaria; Echinochloa senegalensis; Echinochloa verticillata

$30 \quad$ Echinochloa rotundiflora

31 Echinochloa stagnina

Echinochloa barbata; Echinochloa hostii; Echinochloa lelievrei; Echinochloa malakuensis; Echinochloa oryzetorum; Echinochloa scabra

Florida

Tropical Asia to West Pacific

Tanzania

Tropical and subtropical America

Papua New Guinea and Northern territory of Australia

Africa to Arabian Pen

Nigeria to Eritrea

Africa, tropical Asia

South West and East Australia

Central and East Australia

Ethiopia to South Africa

Echinochloa longearistata

Source - Kew Royal Botanical Gardens; http://apps.kew.org/. 


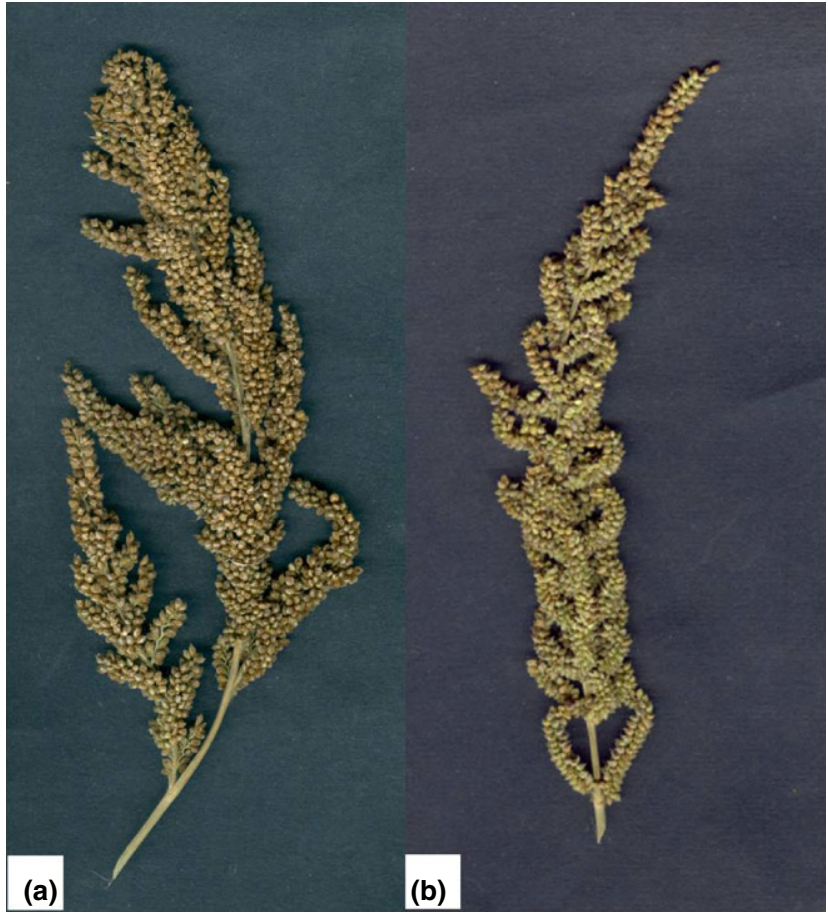

Fig. 1: Panicles of two cultivated species of barnyard millet (a) Echinochloa esculenta (b) Echinochloa frumentacea

branching, more compact growth habit, larger inflorescence, reduced shattering and larger seed size. Yabuno (1975) considered low seed shattering, lack of seed dormancy, thick culms, wide leaves and round spikelets in E. esculenta were the main characters selected by man during the process of domestication. This suite of traits that constitutes 'domestication syndrome' for closely related foxtail millet (Defelice 2002, Doust et al. 2005, Li and Brutnell 2011) and pearl millet (Poncet et al. 1998, 2000) is likely for barnyard millet as well. Increase in seed size in Japanese barnyard millet during domestication is suggested by archaeological data. The mean size of Echinochloa caryopses from the Middle Jomon period (3470 B.C.E. -2420 B.C.E.) was about 20\% larger than specimens from Early Jomon period (5000 B.C.E-3470 B.C.E), indicating that selection for larger seed size was taking place over several millennia in Northern Japan (Crawford 1983, 2011, Takase 2009). The cross-compatibility between domesticated barnyard millet and their ancestral forms and the existence of naturally occurring intergrades between the two forms provide avenues to understand the mechanisms driving domestication and elucidate the genetics of domestication traits in this crop.

\section{Phylogeny}

The members of Echinochloa include minor cereal crops and major weeds in fields. The interspecific relationship is poorly understood due to the high morphological variation. Several attempts aimed at solving the difficulties have led to an ambiguous understanding of phylogenetic relationships among taxa (Hilu 1994, Michael 1994, 2001). The best understanding of this genus has come from series of studies by Yabuno (1962, 1984, 1996, 2001). Two cultivated species, Japanese barnyard millet (E. esculenta) and Indian barnyard millet (E. frumentacea), have a close relationship with their wild counterparts, E. crus-galli and E. co- lona, respectively. Both of the cultivated species as well as their progenitors are hexaploid with $2 \mathrm{n}=6 \mathrm{x}=54$ where $\mathrm{x}=9$ (Yabuno 1962, 1966). Interspecific hybrids obtained by crosses between E. crus-galli $\times$ E. esculenta and E. colona $\times$ E. frumentacea were found to have normal meiotic division with 27 bivalents. The crosses between these two groups, that is, between two cultivated species (E. esculenta $\times$ E. frumentacea) and their ancestors $(E$. crus-galli $\times$ E. colona $)$, resulted in meiotic irregularities, univalents, laggards and micronuclei. These cytogenetic evidences suggested that the hexaploid wild species $E$. colona and E. crus-galli are possible progenitors of E. frumentacea and E. esculenta, respectively, and the two cultivated species have different genomic composition (Yabuno 1966). The crosses between E. crus-galli and E. oryzoides showed 18 bivalents and nine univalents suggesting that two of the three genomes of E. crus-galli are homologous to E. oryzoides and E. crus-galli is an allohexaploid produced through natural hybridization between the tetraploid E. oryzoides with a not-yet-discovered diploid species of Echinochloa (Yabuno 1966, 1984).

On the basis of these crossing experiments and observation of meiotic chromosomal behaviour of interspecific hybrids, Echinochloa species were grouped into several cross-compatible groups, and polyploidization followed with amphidiploidization had taken place in the evolutionary process of species diversification in this genus (Yabuno 1966, 1984, 2001). However, the morphological, reproductive and ecologic traits relied upon by conventional taxonomists for the identification or discrimination of taxa might present ambiguous results due to domestication and adaptive syndromes (Yabuno 1966, 1984, 2001, Yamaguchi et al. 1996).

Later on to understand, genetic relationships among Eurasian annual Echinochloa species molecular markers were used by several workers (Yasuda et al. 2002, Yamaguchi et al. 2005, Ruiz-Santaella et al. 2006). The molecular analysis also confirmed that the Asian annual weedy Echinochloa species including their domesticated counterparts fall into three cross-compatible groups, the Echinochloa oryzicola group, Echinochloa crus-galli complex (group) and Echinochloa colona-frumentacea group (Yamaguchi et al. 2005). Species divergence is well illustrated by the nucleotide sequencing of the particular regions of the cpDNA, and the three groups have shown different cytoplasmic lineages (Yamaguchi et al. 2005). The tetraploid E. oryzicola includes the wild representatives, E. oryzicola (Vasing.) and Echinochloa phyllopogon (Stapf) Koss. and Mosuo barnyard millet. The hexaploid E. crus-galli group consists of four wild E. crus-galli (L.) P. Beauv. varieties - var. crus-galli, var. praticola Ohwi, var. formosensis Ohwi and var. oryzoides (Ard.) Lindm. (syn: Echinochloa oryzoides [Ard.] Fritsch) - and one cultivated species, Echinochloa esculenta (A. Braun) Scholz (Yabuno 1984, 1996). The hexaploid E. colona-frumentacea group consists of wild E. colona (L.) Link and cultivated Echinochloa frumentacea (Roxb.) Link. The hypothesis that E. crus-galli was derived from a hybrid between E. oryzicola and unknown diploid species (Yabuno 1966) was confirmed using internal transcribed spacer and chloroplast DNA sequences by Aoki and Yamaguchi (2008). They found same nuclear lineage between E. oryzicola and E. crus-galli indicating that E. oryzicola is the paternal donor of E. crus-galli. Further, phylogenetic analysis of the sh4 gene (control spikelets shattering) of Oryza detected homoeologue copies in E. oryzicola, E. crus-galli, E. stagnina, E. colona and E. crus-pavonis. This indicated a genomic relationship between the Asian Echinochloa species 
and supported that the allohexaploid E. crus-galli shares two genomes with its parental donor, E. oryzicola. The Asian perennial tetraploid species, E. stagnina, shares one genome with E. oryzicola and possesses an unknown genome, E. cruspavonis, from the New World, shows a close affinity of two genomes with E. crus-galli and E. oryzicola, while E. colona showed distant affinities in all homoeologous copies (Aoki and Yamaguchi 2009).

\section{Botanical Description}

Barnyard millet has a wide adaptation capacity and can grow up to an altitude of $2000 \mathrm{~m}$ above mean sea level during summer season (Gupta et al. 2009a). It is variable in flowering time, inflorescence shape, morphological features, pigmentation of spikelets, plant type and other plant traits (Obara 1938). The crop plant is a tall, robust annual and grows up to $220 \mathrm{~cm}$ high. It has a short generation time, fastest growth among all small millets and completes the life cycle from seed to seed in 45-60 days (depending upon accession and growth environment) (Denton 1987, Padulosi et al. 2009), however, may take longer time under northern hill ecosystem. Hulse et al. (1980) reported that Echinocloa millets grow well in different seasons but at high elevations may require 3-4 months to mature. Leaf blades are flat and wide with no ligules. The inflorescence is a terminal panicle 10-25 cm long with dense racemes of 3- to 4mm-long spikelets (Napper 1965). The inflorescence is usually erect, rarely drooping with shapes varying from cylindrical, pyramidal and globose to elliptic. Racemes are few to numerous, densely crowded with spikelets arranged in four irregular rows on the triquetrous rachis and are loosely or tightly appended on the rachis. The spikelets are green, brown to purple in colour and crowded on one side of the rachis. Spikelets are two flowered, awnless or awned, with red or green awns and placed on short rough pedicels subtended by two glumes (Mitich 1990). Lower floret is neuter (sterile) with lemma and small palea, and upper floret is bisexual (Gupta et al. 2010a). The sterile lemma is 5-veined. Fertile lemma is plano-convex, elliptic, smooth and shiny, abruptly sharp-pointed or cuspidate, and margins are inrolled below over palea with apex of palea not enclosed. The palea is flat, and surface texture is similar to fertile lemma (Napper 1965). Stamens are three in number, and ovary superior contains two distinct styles with plumose stigma (Sundararaj and Thulasidas 1976). Grain is $2-3 \mathrm{~mm}$ long and 1-2 mm wide and enclosed in white shinning hardened lemma and palea.

The flowering starts from top of the inflorescence and moves downward completing in 10-15 days. Flowers open from 5 to 10 am with maximum number of flower opens between 6 and 7 am (Sundararaj and Thulasidas 1976, Jayaraman et al. 1997). In the individual raceme, the flowering first starts at marginal ends and then proceeds to the middle of the raceme. The flowers are hermaphrodite (have both male and female organs). Before the anthers dehiscence, the stigmatic branches spread and flower opens (Seetharam et al. 2003). Late season florets are cleistogamous (not opening) (Maun and Barrett 1986). It is primarily self-pollinating (Maun and Barrett 1986, Potvin 1986, 1991) and self-compatible (Maun and Barrett 1986). Some degree of outcrossing recorded which was facilitated by wind pollination (Maun and Barrett 1986). Hot water treatment of inflorescence at $48^{\circ} \mathrm{C}$ for $4-5 \mathrm{~min}$ (personal observation) was effective in inducing male sterility under hill condition in both the cultivated species.

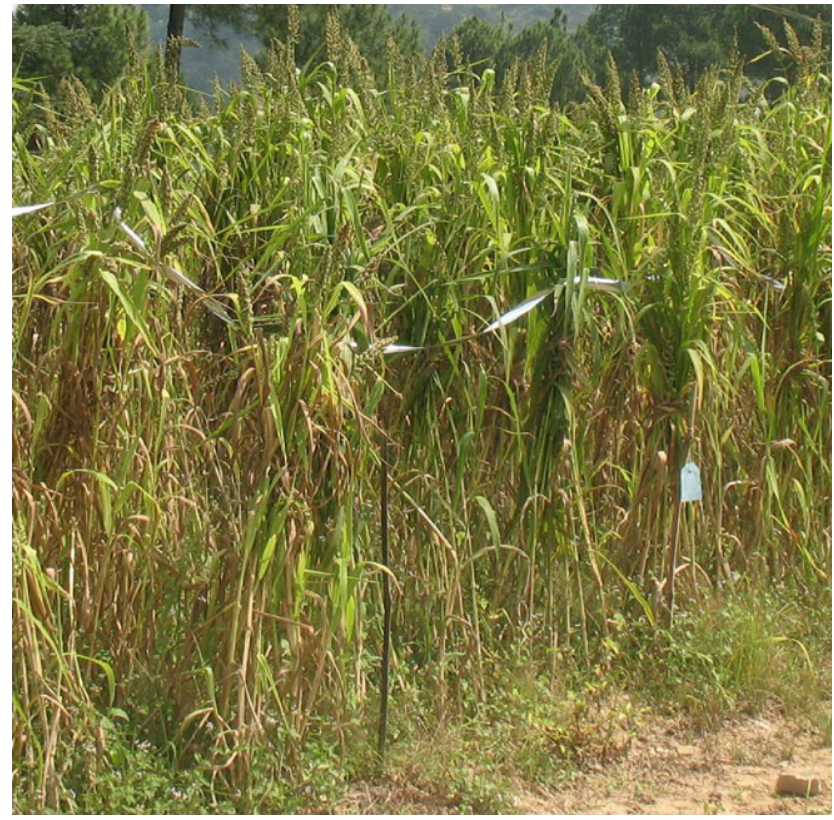

Fig. 2: Barnyard crop trial at VPKAS, ICAR, Almora, Uttarakhand, India

The two cultivated millet species namely Indian and Japanese barnyard millet can easily be distinguished on the basis of panicle morphology, texture of the glumes and lower lemma (Yabuno 1971, 1987, De Wet et al. 1983). Echinochloa frumentacea has smaller awnless spikelets, with membraneous glumes in comparison with large usually awned spikelets and chartaceous upper glumes and lower lemma in E. esculenta. Based on inflorescence morphology, the species E. frumentacea was classified into four races namely Stolonifera, Intermedia, Robusta and Laxa. Similarly, E. utilis (Syn. E. esculenta) was classified into two races namely utilis and intermedia.

The mean diploid 2C DNA content of barnyard millet is reported to be 2.65-2.7 pg bot agr (Schlegel 2010).

\section{Growth and Development}

Barnyard millet grown under natural precipitation is a fast-growing annual summer crop for both food and fodder. Rapid growth, drought tolerance and ability to grow in marginal environments make barnyard millet an important crop for famine areas (De Wet et al. 1983, Kono et al. 1987, Majid et al. 1989) (Fig. 2). The crop seeds germinate within approximately $24 \mathrm{~h}$ of water imbibition (Rahn et al. 1968). After 5 days of emergence, plants produce adventitious roots (Rahn et al. 1968) and the first tillers appear 10 days after emergence (Holm et al. 1991). Temperature plays a major role in the growth of both the species (Holm et al. 1991), and low temperature conditions $\left(15 / 10^{\circ} \mathrm{C}\right.$ day/night $)$ cease the growth and affect the plant development particularly leaf area and dry weight. For proper growth of E. frumentacea, the optimum temperature range is $27-33^{\circ} \mathrm{C}$ and $15-22^{\circ} \mathrm{C}$ day and night, respectively (Muldoon et al. 1982). In high hills of Uttarakhand, E. frumentacea and E. esculenta showed significant variation in seedling emergence and other characters in April sowing, whereas the differences were non-significant in May-June sowing. This is because of E. esculenta had better tolerance to low temperature and showed little reduction in relative growth rate in comparison with E. frumentacea (Muldoon et al. 1982, 
Bandyopadhyay 1999). If conditions are favourable, plants show profuse growth for 3 weeks and the transition from vegetative growth into inflorescence takes place rapidly within approximately 40 days after emergence (Maun and Barrett 1986). Although both the cultivated species have been reported to be quantitative short-day plants (Muldoon 1985), most Echinochloa spp. can grow and reproduce in a range of photoperiods, short days (8-13 h) and long days (16 h) (Maun and Barrett 1986, Mitich 1990). Under short-day conditions, plants are small and flowering is quick, yet abundant; under long-day conditions, the plants are more robust with a large seed output (Maun and Barrett 1986, Manidool 1992). Late plantings shorten the vegetative phase and adversely affect the crop yield. Seeds mature in about 20-40 days after the reproductive phase begins. The optimum time of harvesting in Japanese barnyard millet is 30-35 days after heading (Kumagai et al. 2011), when the moisture content of panicles is $16-18 \%$. Inmate seed dormancy in freshly harvested seeds varies from 4 to 48 months in Echinochloa crus-galli (Maun and Barrett 1986, Sung et al. 1987, Manidool 1992). All Echinochloa species have a $C_{4}$ photosynthetic pathway, show a great competitive advantage when they grow together with $\mathrm{C}_{3}$ crops (Bouhache and Bayer 1993) and perform better than rice under water stress conditions due to high water-use efficiency and $60 \%$ higher carbon efficiency ratio (Migo et al. 1991).

\section{Germplasm and Its Impact}

Diversity in barnyard millet is being fast eroded due to considerable reduction in acreage and changing sociocultural and economic dimensions of the farming community in India (Maikhuri et al. 2001). Considerable efforts have been made to preserve the crop diversity ex situ, but the information regarding on-farm, in situ conservation is very scarce (Padulosi et al. 2009). The largest ex situ collection at international level is maintained by the Consultative Group on International Agricultural Research (CGIAR) with 2365 collections. A few of them (44 accessions) have been duplicated with the Global Crop Diversity Trust for safe storage at the Svalbard Gene Bank in Norway (Padulosi et al. 2009). India holds the largest barnyard millet collection at National Bureau of Plant Genetic Resources (1718 accessions) followed by All India Coordinated Small Millet Improvement Project at the University of Agricultural Sciences, Bangalore, Karnataka (985 accessions). Vivekananda Parvatiya Krishi Anusandhan Sansthan (VPKAS), Almora, is manly maintaining more than 300 local collections of barnyard millet from Uttarakhand. ICRISAT has a total of 743 active collections and 487 base collections from nine countries for research and distribution (Upadhyaya et al. 2008). In addition, the US GRIN database contains 306 accessions of 18 Echinochloa species from 33 countries housed at the National Centre for Genetic Resources Conservation (Fort Collins, Colorado) and a smaller collection of 67 accessions at Australian Plant Genetic Resource Information Service, Biloela (Dwivedi et al. 2012). Notwithstanding the impressive size of global barnyard millet collection at both National and International organizations, it is imperative to analyse and fill germplasm gaps to make the collection more comprehensive. For example, accessions belonging to laxa race endemic to Sikkim state of India hitherto unrepresented in the ex situ collections need to be collected before it becomes extinct (Dwivedi et al. 2012).

Germplasm is the basic material for crop improvement programme in any crop. Descriptor list has been developed and used to characterize barnyard millet germplasm for sets of morphologic and agronomic traits (http://www.ecpgr.cgiar.org/fileadmin/bioversity/publications/pdfs/394_Echinochloa_millet_descriptors.pdf?cache $=1372427061$ ). Phenotypic characterization of the collected materials has indicated that barnyard millet germplasm is highly diverse (Halaswamy et al. 2001, Gowda et al. 2008, Gupta et al. 2009a, Nirmalakumari and Vetriventhan 2009). Statewise grouping of morphological characters of Indian collections of seven states did not reveal concentration of any group to a specific state (Halaswamy et al. 2001). In a similar study, different genotypes clustered together irrespective of their place of origin suggesting that geographical isolation was not the only factor causing genetic diversity (Mehta et al. 2005, 2007). Similar results were also observed by Prabha et al. (2010) where the accessions of two different cultivated species of barnyard millet clustered together although, with the help of isozyme markers, they also found accessions within each species forming two different clusters, which is consistent with the morphological evidence on existence of intergrades and overlaps between the two species. On the basis of principal component analysis of quantitative traits, Gupta et al. (2009a) classified 194 barnyard accessions of Indian origin into three races robusta, intermedia and stolonifera on the basis of resemblance of morphological traits of the accessions with these races. Race laxa, however, was absent in the group.

For optimum and precise utilization of diversity for agronomic and nutritional improvement, a core collection representing 50 and 89 accessions has been developed by Gowda et al. (2009) and Upadhyaya et al. (2014), respectively. Halaswamy et al. (2001) characterized the national collection and identified promising accessions for higher plant height (seven accessions), higher number of basal tillers (nine accessions), longer inflorescence (10 accessions) and early flowering ( 27 accessions). New lines, IEC 566 and IEC 566/2, which differ in several aspects from cultivated varieties and produce abundant pollen grains and have flowers that open for a long time with stigma protruding enough to facilitate emasculation and pollination, have also been identified (Nirmalakumari and Vetriventhan 2009). Similarly, an easy dehulling accession B29 was identified in accessions from Uttarakhand hills. The dehulled grain recovery of B29 was 40\% and $140 \%$ higher than the check varieties VL 172 and PRJ 1, respectively. The accession is registered with NBPGR vide number INGR09023 (Gupta et al. 2009b).

Characterization and evaluation of germplasm for important agronomic traits constitutes the most critical component driving utilization of germplasm by crop breeders. Utilization of barnyard millet genetic resources for crop improvement falls far short of the desired. The release of variety PRJ 1, which was a direct selection from ICRISAT germplasm, in 2003 for Uttarakhand state is among few notable examples of effective utilization of barnyard millet germplasm. The variety yielded $45.4 \%$ higher than the check variety VL 29 (Upadhyaya et al. 2008). PRJ 1 belongs to E. esculenta, whereas all the existing adapted material in Uttarakhand hills was of species E. frumentacea. Much, therefore, needs to be carried out to enhance utilization of barnyard millet germplasm for genetic improvement of the crop.

\section{Breeding Objectives and Achievements}

Echinochloa species show a high degree of autogamy, but the rate of cross-pollination is sufficient to assure gene exchange among their populations (Maun and Barrett 1986). Emasculation and artificial hybridization is difficult due to small flower size, 
early hours of flowering, short viability of pollen, non-availability of pollen grain and slight opening of flowers that too for a short period (Nirmalakumari and Vetriventhan 2009). The crop is still considered as a minor food and feed crop of poor tribal people, has not attracted research efforts like other major crop plants and very limited work has been carried out for its improvement. In India, barnyard millet breeding is carried out mainly in the states of Uttarakhand and Tamil Nadu. Thus far, more than 20 improved cultivars have been developed and released for different barnyard millet growing regions of the country. Mass selection and pure line selection have remained the major breeding strategies for the improvement of the crop; however, some varieties have been developed through hybridization followed by pedigree method of selection.

Although it is difficult to induce a mutant phenotype in a polyploid species like Echinochloa, full waxy stable mutant lines have been developed through $\gamma$ irradiation of low amylase landrace 'Nogehie' (Hoshino et al. 2010). Gamma irradiation also increased genetic variance for tiller number, plant height, head length and grain yield (Mehra et al. 1985). Mehta et al. (2005) emphasized interspecific hybridization programme involving early maturing E. frumentacea and high-yielding E. esulenta to develop early maturing high-yielding segregants. However, hybrids between $E$. frumentacea and $E$. esculenta are sterile both ways, whereas those with its wild progenitors are fertile. These wild progenitors can provide valuable genetic resources for the improvement of cultivated species (Mandelbaum et al. 1995). Large variation in protein and calcium values within accessions of a species suggests selective breeding for nutritive values (Mandelbaum et al. 1995).

Barnyard millet can grow up to $2 \mathrm{~m}$ or more under high moisture conditions prevalent during rainy season in India, making it prone to lodging. Reducing plant height to about $120-130 \mathrm{~cm}$ could minimize the problem. The resultant reduction in fodder yield may be compensated by developing genotypes with higher number of basal tillers, adding to grain yield as well. In barnyard millet, the length and number of spikes is positively correlated with grain yield. Developing genotypes with more and longer spikes should be the principal approach for enhancing grain yield. Breeding for easy dehulling is another important breeding objective to reduce the drudgery involved in postharvest processing of barnyard millet. Availability of easy dehulling types has been reported in the local germplasm (Anonymous 2010), which can be used to transfer the trait to high-yielding adapted cultivars. As barnyard millet is traditionally consumed just like rice, increasing grain size is likely to enhance its appeal among the consumers. This, however, remains a challenge due to narrow range of variability for the trait.

Among biotic stresses, grain smut caused by Ustilago spp. is a major yield constraint in barnyard millet causing yield losses of up to $60.8 \%$ (Jain et al. 1997). Source of resistance to grain smut is not reported in Indian barnyard millet, while Japanese barnyard millet is near immune to the disease. The transfer of resistance from Japanese to Indian barnyard millet, however, is hampered by sterility in the hybrids between the two species (Sood et al. 2014). The wild progenitor of Indian barnyard millet, E. colona, which is resistant to grain smut as well as crossable with cultivated barnyard millet may be an alternate source for the trait. Breeding efforts should also be directed towards resistance to Helminthosporium leaf blight which is a serious problem in specific areas.

Improvement in grain yield remains the most important breeding objective in barnyard millet. A wide production gap still exists between yields realized at farmer's fields because of prevalence of local cultivation practices (Gupta et al. 2006). Most of barnyard-millet-growing areas are still under local cultivars and land races with low grain yields of 1.0-1.5 tons per hectare, whereas the crop has the potential of $>2.0$ tons/ha (Harinarayana 1989) and yield levels of 3.0 tons/ha have been reported in the E. esulenta lines (Bandyopadhyay 2001). Improved varieties coupled with modern agronomic practices can bring about significant improvement in barnyard millet productivity and bridge the production gap. Barnyard millet straw is preferred over rice straw. Therefore, selection of variety which could give high grain as well as high fodder is the best alternative.

\section{Fodder Quality}

Barnyard millet grows rapidly and produces voluminous fodder. Its fodder is highly palatable and can be used for making hay or silage. It is considered superior to rice and oat straw because of high protein and calcium content (Yabuno 1987). Barnyard millet straw contains up to $61 \%$ total digestible nutrients and good amount of protein and digestible fibre (National Research Council 1996). The average dry fodder yield of barnyard under Indian conditions is 5 tons/ha (AICSMIP 2014). In Uttarakhand hills of India, barnyard millet fodder contributes $11.5 \%$ of the total fodder consumption of the State (Singh and Singh 2005), where even grains of Indian barnyard millet are also fed to animals. Recent studies revealed that Japanese barnyard millet has higher fodder production potential than Indian barnyard millet, and recommended fertilizer application significantly enhances the fodder yield in barnyard millet (Yadav and Yadav 2013). Japanese barnyard millet has also been found superior than Indian barnyard millet under double fodder cutting management for dual purpose use (Bandyopadhyay 2009). However, non-significant differences were observed between the two species for dry matter digestibility (Unpublished data).

In Australia, China and the United States of America, Japanese barnyard millet is grown for grazing or hay. In United States of America, it is reported to produce eight harvests per year (Kajuna 2001). It has the highest protein content of all the millet species (http://www.fao.org/docrep/008/y5831e/y5831e06. htm). In Australia, it has been recognized as a valuable shortterm rotation crop for spring-early summer grazing. The rapid early growth of the crop can fill feed shortfalls in early summer after floods or drought. The crop gives two good grazings in northern New South Wales and repeated grazing in the cooler southern areas. The major weakness of the crop is quick heading under hot and dry conditions (Dairy Link-Establishing pasturesPasture Species http://www.dpi.nsw.gov.au/_data/assets/ pdf_file/0018/163116/establishing-pastures-1-5.pdf).

It has superior feed quality when fed young to the animals (Metabolizable energy $8.5-9.5 \mathrm{MJ} / \mathrm{kg}$ ); however, protein content declines from $25 \%$ to $6 \%$ at maturity. In Kyabram, Australia, Echinochloa millet cv. 'Shirohie' produced dry matter $(\mathrm{DM})$ and digestible dry matter (DDM) (16.3 t/ha, $10.8 \mathrm{t} /$ ha) equivalent to sorghum $\times$ sudan grass hybrid cv. 'Sudax' $(17.1 \mathrm{t} \mathrm{DM} / \mathrm{ha}$ and $10.7 \mathrm{t} / \mathrm{ha})$ and showed higher digestibility $(65.9 \%)$ and nitrogen concentration (1.9\%) than sorghum $\mathrm{x}$ sudan hybrids $(63.3 \%$ dry matter digestibility, $1.5 \%$ N). Similar studies in Bangladesh also showed higher productivity and better nutritive value of Echinochloa crus-galli L. (Kanak et al. 2013). 


\section{Genomic Resources and Molecular Breeding Advancements}

The use of molecular markers in barnyard millet closely followed their use in other small millets such as finger millet and foxtail millet. Hilu (1994) using RAPD markers observed high degree of variability in Indian barnyard millet (E. frumentacea) in consistency with high degree of morphological variability observed in this species. Danquah et al. (2002) developed five primer pairs of microsatellite loci for studying genetic diversity and interspecific classification of three agronomically important Echinochloa spp viz., E. crus-galli (L.) Link., E. colona (L.) Beauv. and E. crus-pavonis (Kunth.). They reported that microsatellites were useful in discriminating the three species and could aid in classification of species within this complex genus. SSR markers were used by Nozawa et al. (2006) to study population structure and diversity of 155 accessions of barnyard millet including 49 from var. esculenta, 94 from var. crus-galli and 12 from var. formosensis. The SSR markers clustered the esculenta accessions into two groups, crus-galli accessions into 12 groups and formensis accessions into six groups. The results also revealed that accessions belonging to var. esculenta were less diverse than those of var. crus-galli or var. formosensis. The information on genomic resources in barnyard millet is meagre; however, foxtail millet has emerged as a model crop for studying the system biology of other millets due to the availability of genomewide sequence resources. In foxtail millet, large-scale development of molecular markers such as SSRs (Pandey et al. 2013), EST-derived SSRs (Kumari et al. 2013) and ILPs (Muthamilarasan et al. 2014) was reported along with the demonstration of these markers in germplasm characterization, transferability, phylogenetics and comparative mapping studies in millets and bioenergy grasses (Muthamilarasan et al. 2014). In addition, a unique web-based Foxtail millet Marker Database (FmMDb) had also been constructed (Venkata Suresh et al. 2013) for access of breeders and researchers to these marker resources. The high levels of transferability in these studies substantiate the applicability of sequence-based markers in comparative genome mapping and evolutionary studies in other grass species including barnyard millet where the crosstransferability was more than $90 \%$ (Table 2) and was placed in same group with foxtail varieties and species (Yadav et al. 2014). The development and large-scale validation of such genomic microsatellite markers in a genomewide scale could be useful for barnyard millet also, for which very little or no genomic information is available (Lata et al. 2013). Molecular breeding studies such as genetic diversity, linkage mapping and identification of QTLs require a large number of molecular markers. As there is no genome sequence information available in barnyard millet, comparative genomics plays an important

Table 2: Percentage transferability of foxtail sequence-based genetic markers in barnyard millet

\begin{tabular}{llcl}
\hline S1 No. & $\begin{array}{c}\text { Marker type } \\
\text { and number }\end{array}$ & $\begin{array}{c}\text { Percentage } \\
\text { transferability }\end{array}$ & \multicolumn{1}{c}{ References } \\
\hline 1 & SSR, 58 & 91.3 & Pandey et al. (2013) \\
2 & EST SSR, 106 & 90.6 & Kumari et al. (2013) \\
3 & ILP, 100 & 94.1 & Muthamilarasan et al. (2014) \\
4 & miRNA, 66 & 89 & Yadav et al. (2014) \\
\hline
\end{tabular}

SSR, simple sequence repeat; EST, expressed sequence tag; ILP, intron length polymorphism; miRNA, micro-ribonucleic acid. role. In this concern, the primary studies conducted earlier in foxtail millet (Kumari et al. 2013, Pandey et al. 2013, Muthamilarasan et al. 2014, Yadav et al. 2014) will help in barnyard crop improvement through molecular approaches. The identified SSRs can be utilized in the genetic diversity studies, linkage map construction and their further use in identification of markers linked to the QTLs of important agro-morphological characters in barnyard millet. The identified QTLs can be effectively introgressed in the locally adapted genotypes of barnyard millet for yield improvement and stress amelioration through marker-assisted selection.

Besides the use of molecular markers, literature abounds in reports of successful callus and plant regeneration in E. frumentacea (Talwar and Rashid 1989, Sankhla et al. 1992, Bobkov 2005), E. crus-galli (Gupta et al. 2001) and E. colona (Tyagi et al. 1985, Samantaray et al. 1995, 1996, 2001, Rout et al. 1997). Bobkov (2005) optimized the media to maintain viable callus of E. frumentacea for many years. He cultured the seeds in $2 \mathrm{KC}$ media which contained salts according to the MS medium and vitamins according to the B5 medium, $100 \mathrm{mg} / \mathrm{l}$ myo-inositol, $4 \mathrm{~g} / \mathrm{l}$ sucrose, $2 \mathrm{mg} / \mathrm{l}$ glycine, $6 \mathrm{~g} / \mathrm{l}$ agar and $2 \mathrm{mg} /$ $12,4-D$. There is only one preliminary study of transformation in barnyard millet (Gupta et al. 2001) which was carried out along with finger millet for assessment of the efficiency of five gene promoters (CaMV35, Actl, uql, rice ribulose 1, 5-biphosphate carboxylase small subunit (RbcS) and Flaveria trinervia $(\mathrm{Ft}))$. In barnyard millet, only the uq1 promoter was effective for the expression of GUS gene; other four promoters (CaMV35S, Act1, RbcS and Ft) were ineffective based on the histochemical analysis.

\section{Nutritional Importance and Antinutritional Compounds}

Both the cultivated species have higher protein content than their wild ancestors. The protein content in barnyard millet ranged from $11.1 \%$ to $13.9 \%$ (Monteiro et al. 1987). However, the reverse is true for mineral content which suggests that wild species might consist of greater proportion of embryo/endosperm because of selection of larger seeds that increases endosperm size (Mandelbaum et al. 1995). The barnyard millet grain contains about $65 \%$ carbohydrate, majority of which is in the form of non-starchy polysaccharide and dietary fibre. This helps in the prevention of constipation, lowering of blood cholesterol and slow release of glucose into the blood stream during digestion. Barnyard millet has been found to be most effective in reducing blood glucose and lipid levels compared to other millets (Proso, Foxtail, Kodo and Little millet) and rice (Krishna Kumari and Thayumanavan 1998). There are several other reports suggesting effectiveness of barnyard and its products for diabetics (Arora and Srivastava 2002, Surekha 2004, Ugare et al. 2014). Polishing barnyard millet results in loss of fibre and other nutritional components, and maximum loss occurs at $14 \%$ moisture level (Lohani et al. 2012). Barnyard has non-glutinous type of endosperm (Tomita et al. 1981). Starch of barnyard millets was more digestible than maize starch in terms of in vitro amylolysis by pancreatic amylase (http://www.fao.org/docrep/T0818E/ T0818E0c.htm\#Carbohydrate). However, high fibre content and poor digestibility of nutrients adversely affects consumer acceptability of all small millets. The nutritional potential of millets is limited by the presence of phytates, phenols and tannins. Kulkarni et al. (1992) assessed the tannin content of five minor millets viz., proso, kodo, Italian, little and barnyard millet and recorded 
lowest level in barnyard millet $(102.96 \mathrm{mg})$. It has been shown that dehulling of the seeds reduces phytate and tannin levels (Lorenz 1983, Kulkarni et al. 1992).

Recently, the demand of barnyard millet has increased due to its highly nutritious grains and presence of strong antioxidative compounds (Watanabe 1999). He isolated three antioxidative phenolic compounds, one serotonin derivative and two flavonoids, from Japanese barnyard millet (cv. 'Kurohie') grains. High nutrient content and antioxidant effects make barnyard millet to be considered as a functional food crop (Kim et al. 2011), and the crop has potential to be included in normal and therapeutic diet formulations (Veena et al. 2005). Gluten presence in main cereal crops such as wheat make them allergic to some people, but barnyard millet grains are gluten free and, therefore, offer good opportunity for their use as health foods also (Hoshino et al. 2010).

Millets as a group contain several antinutritional compounds such as polyphenols, tannins, phytic acid and phytate, goitrogens and oxalic acid. The presence of antinutrients such as phytate, polyphenols, oxalates and tannins affect the mineral bioavailability. These antinutrients form complexes with dietary minerals, such as calcium, zinc and iron, leading to a marked reduction in its bioavailability and make them biologically unavailable to human organism (Arora et al. 2003). Polyphenols and tannin compounds are concentrated in the bran and affect in vitro protein digestibility. Oxalic acid forms an insoluble complex with calcium and thereby reducing its biological availability. The work on antinutritional compounds in barnyard millet is very limited, and there are no reports of any kind of antinutritional compounds in barnyard millet (Dwivedi et al. 2012). A study by Gupta et al. (2013) also showed that the total tannin content (0.301), oxalate content (0.02) and trypsin inhibitor activity (31.95) were well below the threshold level and cyanide content and haemagglutinin activity were absent in two National varieties VL 29 and VL 172 of Indian barnyard millet. However, we have to wait for much more reports to draw any valid conclusion on the presence of antinutritional compounds in barnyard millet.

\section{Diseases and Insect Pests}

Grain smut, caused by Ustilago panici-frumentacei Brefeld, is the major disease in barnyard millet (Fig. 3). In the infected panicles, the flower ovaries are round and hairy and may enlarge 2-3 times than normal size. Sometime, gall-like swellings are also observed on the nodes, axils of the older leaves and the

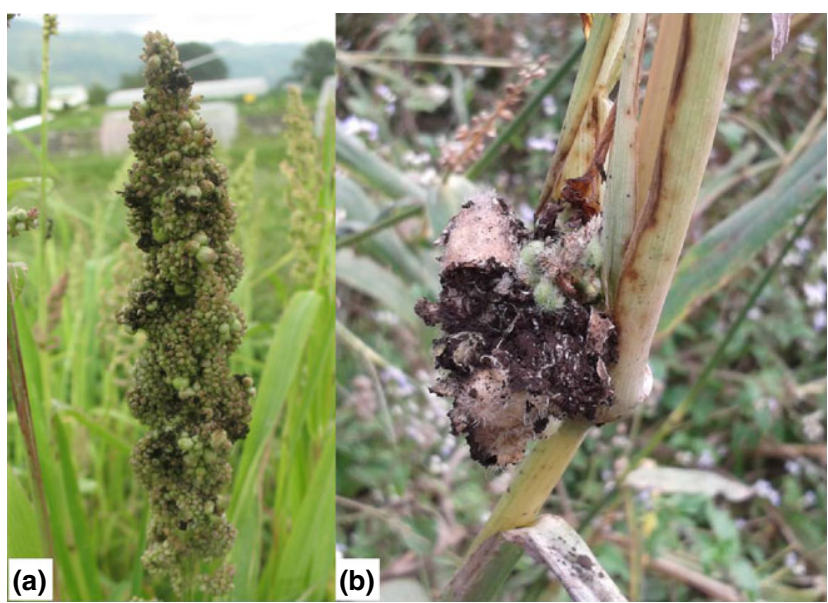

Fig. 3: Smut in barnyard millet (a) grain smut (b) head smut stem. This disease is called head smut and is caused by Ustilago crus-galli Tracy and Earle (Nagaraja et al. 2007). This occurs late in the season when the crop is about to mature.

Phenotypic screening for grain smut allowed identification of disease-resistant germplasm. Natural intensity of $0-75 \%$ at maturity has been reported by Pawar et al. (1982). Two accessions (PRB 9402 and PRB 9602) belonging to E. esculenta showed immune reaction to grain smut at Almora (AICSMIP 2001); however, two separate studies at two locations in India (Almora and Bangalore) failed to identify a single accession of $E$. frumentacea immune to disease (Nagaraja and Mantur 2008, Gupta et al. 2010b). Nevertheless, availability of variation for grain smut resistance, particularly low grain smut incidence in accessions of different origin groups (Bihar and Karnataka), provides opportunity to significantly enhance the resistance level through hybridization and selection (Gupta et al. 2010b). More research input is needed to identify sources of resistance to grain smut in Indian barnyard millet.

Other diseases of minor importance in the crop are anthracnose, Cercospora leaf spot (Cercospora fujimaculans), leaf blight (Exserohilum monoceras) and sheath blight (Rhizoctonia solani) (http://www.nilgs.affrc.go.jp/db/diseases/contents/edisease.htm)

The causal organism of the anthracnose disease is Colletotrichum echinochloe (Moriwaki and Tsukiboshi 2009) and is distinct from $C$. graminicola which was earlier considered as the causal organism for the disease in the crop.

The major insect pests of barnyard millet are pink stem borer (Sesamia inferens) (Fig. 4) and shootfly (Altherigona falcata) (Jagadish et al. 2008). The pink stem borer tunnels the stem resulting in dead heart/white head formation, while the shootfly causes tunnelling in the nursery stage. The crop has long storage life and keeping quality and is practically free of stored grain pests.

\section{Postharvest Processing}

Barnyard millet grain requires dehulling prior to making it suitable for human consumption (Lohani et al. 2012). The dehulling is conventionally performed by repeated pounding in mortar, which is time consuming and also labour intensive as the grains

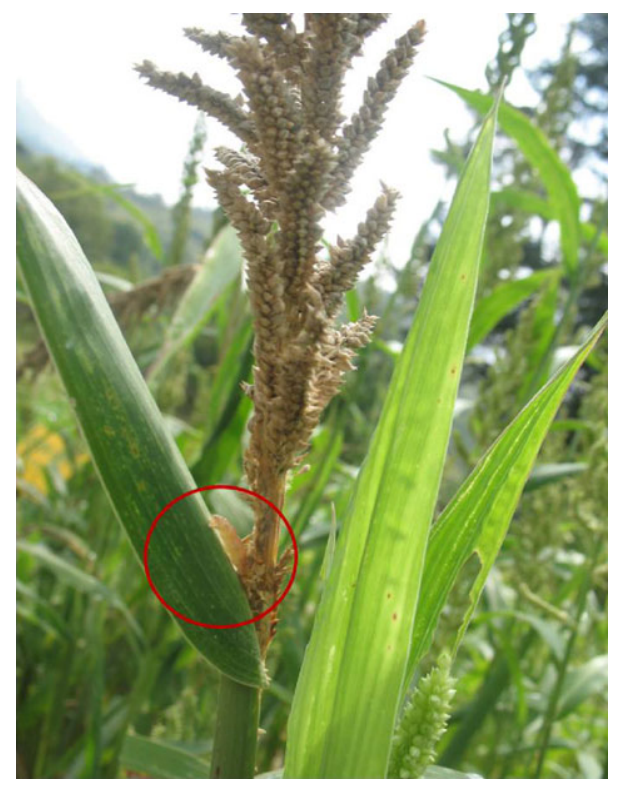

Fig. 4: Stem borer and its damage in barnyard millet 
are firmly encased in the lemma and palea. The drudgery involved in manual processing is an important factor contributing to reduction in consumption of millets. The small seed size also makes processing of these crops difficult. To reduce the drudgery, Singh et al. (2003) developed Vivek Millet Thresher 1, which can thresh 40-60 kg barnyard millet grains per hour. This machine is suitable for marginal farmers in hilly and tribal areas due to its low cost, small size, light weight and ability to do both threshing and dehusking. The machine can dehusk 5 $6 \mathrm{~kg}$ grains per hour by changing the sieves but require 3-4 passes. Another similar easy-to-use affordable mill has been developed through collaborative efforts by Indian and Canadian researchers, which is $98 \%$ efficient in dehusking with $<2 \%$ broken grains. This machine produces about $2 \mathrm{~kg}$ clean seed in an hour. Higher capacity machines/mills, which can process $100 \mathrm{~kg} / \mathrm{h}$, are also available for large farms. These machines with higher capacities have been designed for dehusking only. One such machine developed by Central Institute of Agricultural Engineering (CIAE, ICAR), Bhopal, India, has a capacity of dehusking and grinding $100 \mathrm{~kg}$ in an hour at $10-12 \%$ moisture content. It operates with one-horsepower single-phase electric motor and can even process one $\mathrm{kg}$ of grains also. These machines can significantly reduce the work load and time for postharvest processing of small millets.

\section{Uses}

In the Indian Himalayan region, barnyard millet is traditionally used a substitute for rice. The grains are dehulled, cooked and consumed like rice. Barnyard millet porridge (locally called madira ki kheer) is a popular sweet dish in Uttarakhand. In southern India, barnyard millet is used in traditional preparations such as idli, dosa and chakli. The millet has also been used to develop products such as biscuits, sweets, noodles, rusk, ready mix, popped products and some other speciality foods (Arora and Srivastava 2002, Poongodi et al. 2003, Veena et al. 2004, Ugare 2008), but large-scale production needs industry involvement to commercialize the products globally.

Barnyard millet is highly suitable for commercial foods for diabetics, infants and pregnant women because of high iron content. However, the non-availability of ready-to-use processed products has limited the usage and acceptability of barnyard millet, despite its nutritional superiority. There is a need to develop millet-based food products in the form of ready-to-use products and functional foods to meet the demands of the present-day consumers. Value addition to minor millets not only offers variety, convenience and quality food to consumers, but is important for revival of barnyard millet cultivation as well.

Barnyard millet is also an important source of fodder in the Himalayan region. Barnyard millet leaves are broad, and the plant picks up good growth in short time and thus produces voluminous fodder. Barnyard fodder is highly palatable and can be used for making hay or silage.

\section{Future Scope of Work and Prospects}

The genetic base of cultivated barnyard millet is relatively narrow particularly with respect to traits such as disease resistance and seed size. The genetic base of the crop can be broadened by exploiting the wild relative gene pool, particularly the progenitors. The introgression of traits from the wild relatives can be facilitated by developing closely linked markers for these traits.
Interspecific hybridization between Indian and Japanese barnyard millet offers a promising avenue for mutual genetic improvement of the two species. The fertility barriers between the two species need to be analysed, and modern biotechnological tools employed to overcome them. There is also a need to systematically analyse the available genetic diversity to identity sources of agronomically important traits such as higher yield, disease resistance, nutritional quality of the grain and others. Molecular breeding efforts in barnyard millet lag considerably behind those in other small millets such as foxtail millet (genome sequenced) and finger millet (genetic map developed). Development of a genetic map will greatly boost the breeding efforts towards targeted improvement of barnyard millet. Availability of foxtail millet genome sequence will be enormously advantageous for comparative genomics, genome mapping, marker development and molecular breeding of barnyard millet. These genomic microsatellite markers of foxtail millet showing cross-transferability in barnyard millet would be of enormous and immense use for various large-scale genotyping applications, including germplasm characterization, cultivar identification and QTL discovery. High levels of transferability of ILP markers also demonstrate the usability as anchor markers for comparative genome mapping and understanding phylogenetics across diverse crop species, which eventually will be helpful for map-based isolation of genes in crop plants.

On a worldwide scale, barnyard millet like all other small millets is losing its importance as a food crop in competition with major cereals such as wheat, rice, maize and sorghum. The decline in production has resulted in reduced consumption, which could also be attributed to changing lifestyle and government policies. Drudgery associated with processing of the crop has also contributed to decline in area and production of the crop. However, because of its short crop cycle and ability to grow on a wide range of soil types, it may continue to remain a useful crop in Asia on poor agricultural land in regions with low rainfall or a short growing season. The prospects for barnyard millet in India seem limited, but the crop may gain importance as a niche crop in dry regions at medium to high altitudes under changing climate conditions. Millets have been referred as climate-resilient crops because of their greater ability to resist biotic and abiotic stresses. This offers an additional advantage for this crop, and the potential can be harnessed by concerted research efforts. Collective actions including public awareness on nutritional value, enhanced research on issues associated with crop production, processing and utilization, value addition and government support for marketing could save the crop for future.

\section{References}

AICSMIP, 2001: Annual Report 2000-2001. All India Coordinated Small Millet Improvement Project (ICAR), Bangalore, PP6.

AICSMIP, 2014: Annual Report 2013-2014. All India Coordinated Small Millet Improvement Project (ICAR), Bangalore, BR122.

Anonymous, 2010: Annual Report 2009-2010. Vivekananda Parvatiya Krishi Anusandhan Sansthan (ICAR) Almora-263601, Uttarakhand, 23

Aoki, D., and H. Yamaguchi, 2008: Genetic relationship between Echinochloa crus-galli and Echinochloa oryzicola accessions inferred from internal transcribed spacer and chloroplast DNA sequences. Weed Biol. Manag. 8, 233-242.

Aoki, D., and H. Yamaguchi, 2009: Oryza sh4 gene homologue represents homoeologous genomic copies in polyploid Echinochloa. Weed Biol. Manag. 9, 225-233. 
Arora, S., and S. Srivastava, 2002: Suitability of millet based food products for diabetics. J. Food Sci. Technol. 39, 423-428.

Arora, P., S. Sehgal, and A. Kawatra, 2003: Content and HCl-extractability of minerals as affected by acid treatment of pearl millet. Food Chem. 80, 141-144.

Bandyopadhyay, B. B., 1999: Genotypic differences in relation to climatic adaptation of two cultivated barnyard millet species at Garhwal Hills. Indian J. Genet. 59, 105-108.

Bandyopadhyay, B. B., 2001: Climatic influence on grain yield of barnyard millet (Echinochloa crus-galli subsp utilis) at high hills in Garhwal Himalayas. Indian J. Agric. Sci. 71, 788-790.

Bandyopadhyay, B. B., 2009: Evaluation of barnyard millet cultivars for fodder yield under single and double cut treatments at higher elevations of hills. Agric. Sci. Digest 29, 66-68.

Bobkov, S. V., 2005: Long-term regeneration in callus culture of paisa (Echinochloa frumentacea Link.). Inter. Sorghum Millets Newslett. 46 $120-122$.

Bouhache, M., and D. E. Bayer, 1993: Photosynthetic response of flooded rice (Oryza sativa) and three Echinochloa species to changes in environmental factors. Weed Sci. 41, 611-614.

Clayton, W. D., and S. A. Renvoize, 2006: Genera Graminum: Grasses of the world. Kew Bulletin Additional Series XIII, Royal Botanical Gardens Kew, Her Majesty Stationery Office, London.

Crawford, G. W., 1983: Paleoethnobotany of the Kameda Peninsula Jomon. Anthropology Papers, no. 73. Museum of Anthropology, University of Michigan, Ann Arbor, MI.

Crawford, G. W., 2011: Advances in understanding early agriculture in Japan. Curr. Anthropol. 52(Suppl. 4), 331-345. Doi:10.1086/ 658369.

Danquah, E. Y., S. J. Hanley, R. C. Brookes, C. Aldam, and A. Karp, 2002: Isolation and characterisation of microsatellites in Echinochloa (L.) Beauv. spp. Mol. Ecol. Notes 2, 54-56.

De Wet, J. M. J., K. E. P. Rao, M. H. Mengesha, and D. E. Brink, 1983: Domestication of Sawa millet (Echinochloa colona). Econ. Bot. 37, 283-291.

Defelice, M. S., 2002: Green foxtail, Setaria viridis (L.) P. Beauv. Weed Technol. 16, 253-257.

Denton, D. C., 1987: Food crops for waterfowl. In: D. E. Wesley, and W. G. Leitch (eds), Fireside Waterfowler: Fundamentals of Duck and Goose Ecology, 352. Stackpole Books, Harrisburg, PA

Doggett, H., 1989: Small millets-a selective overview. In: A. Seetharam, K. W. Riley, and G. Harinarayana (eds), Small Millets in Global Agriculture, 3-18. Oxford \& IBH, New Delhi.

Doust, A. N., K. M. Devos, M. D. Gadberry, M. D. Gale, and E. A. Kellogg, 2005: The genetic basis of inflorescence variation between foxtail and green millet (Poaceae). Genetics 169, 1659-1672.

Dwivedi, S., H. Upadhyaya, S. Senthilvel, C. Hash, K. Fukunaga, X. Diao, D. Santra, D. Baltensperger, and M. Prasad, 2012: Millets: genetic and genomic resources. Plant Breed Rev. 35, 247375 .

Gowda, C. L. L., H. D. Upadhyaya, V. G. Reddy, and S. Singh, 2008 Diversity in Small Millets Germplasm and Enhancing its Use in Crop Improvement. Available at: http://www.intlcss.org/files/congress-proceedings/2008-papers/cs2-s1/cs2-s1-o2-laxmipathi-c-1-gowda.pdf (last accessed on July 21, 2014).

Gowda, J., S. Bharathi, G. Somu, M. Krishnappa, and D. Rekha, 2009: Formation of core set in barnyard millet [Echinochloa frumentacea (Roxb.) Link] germplasm using data on twenty four morpho-agronomic traits. Int. J. Plant Sci. 4, 1-5.

Gupta, P., S. Raghuvanshi, and A. K. Tyagi, 2001: Assessment of the efficiency of various gene promoters via biolistics in leaf and regenerating seed callus of millets, Eleusine coracana and Echinochloa crusgalli. Plant Biotechnol. 18, 275-282.

Gupta, A., V. Mahajan, K. P. Singh, and J. C. Bhatt, 2006: Production technology of minor millets for North-Eastern Region. Technical Bulletin 24 (1/2006) VPKAS, Almora.

Gupta, A., V. Mahajan, M. Kumar, and H. S. Gupta, 2009a: Biodiversity in the barnyard millet (Echinochloa frumentacea Link, Poaceae) germplasm in India. Genet. Resour. Crop Evol. 56, 883-889.
Gupta, A., V. Mahajan, H. S. Gupta, K. P. Singh, and G. S. Bisht, 2009b: Kagazi madira (B 29) (IC568707; INGR09023), a Barnyard millet (Echinochloa frumentacea) germplasm, easy de-hulling type. Indian J. Plant Genet. Resour. 22, 281-317.

Gupta, A., V. Mahajan, and H. S. Gupta, 2010a: Genetic resources and varietal improvement of small millets for Indian Himalaya. In: L. M. Tewari, Y. P. S. Pangtey, and G. Tewari (eds), Biodiversity Potentials of the Himalaya, 305-316. Gyanodaya Prakashan, Nainital, India.

Gupta, A., D. Joshi, V. Mahajan, and H. S. Gupta, 2010b: Screening barnyard millet germplasm against grain smut (Ustilago panici-frumentacei Brefeld). Plant Genet. Resour. 8, 52-54.

Gupta, S., S. K. Shrivastava, and M. Shrivastava, 2013: Study of biological active factors in some new varieties of minor millet seeds. Int. J. Innov. Eng. Technol. 3, 115-117.

Halaswamy, B. H., G. V. Srinivas, B. M. Ramakrishna, V. K. Magar, M. Krishnappa, and J. Gowda, 2001: Characterization and preliminary evaluation of national collections of Barnyard millet (Echinochloa spp.) germplasm. Indian J. Plant. Genet. Resour. 14, 213-216.

Hammer, K., 1984: The domestication syndrome. Kulturpflanze 32, 11 34.

Hammer, K., 2003: Evolution of cultivated plants and biodiversity. Nova Acta Leopoldina NF 87, 133-146.

Harinarayana, G., 1989: Breeding and varietal improvement of small millets in India. In: A. Seetharam, K. W. Riley, and G. Harinarayana (eds), Small Millets in Global Agriculture, 59-70. Oxford \& IBH Publishing Co, New Delhi.

Hilu, K. W., 1994: Evidence from RAPD markers in the evolution of Echinochloa millets (Poaceae). Plant Syst. Evol. 189, 247-257.

Holm, L. G., D. L. Plunknett, J. V. Pancho, and J. P. Herberger, 1991: The World's Worst Weeds. Distribution and Biology. Krieger Publishing Company, Malabar, FL 609pp.

Hoshino, T., T. Nakamura, Y. Seimiya, T. Kamada, G. Ishikawa, A. Ogasawara, S. Sagawa, M. Satto, H. Shimizu, M. Nishi, M. Watanabe, J. Takeda, and Y. Takahata, 2010: Production of a full waxy line and analysis of waxy genes in the allohexaploid crop, Japanese Barnyard millet. Plant Breed. 129, 349-355.

Hulse, J. H., E. M. Laing, and O. E. Peason, 1980: Sorghum and Millets: Their Composition and Nutritive Value. Academic Press, London.

Jagadish, P. S., H. K. Mohapatra, M. K. Chakravarthy, N. Srivastava, and N. Nangia, 2008: A Compendium of Insect Pests of Finger Millet and Other Small Millets. All India Coordinated Small Millets Improvement Project, GKVK, Bangalore, 60pp.

Jain, A. K., S. K. Jain, and H. S. Yadava, 1997: Assessment of yield losses due to grain smut in barnyard millet. Indian Phytopathol. 50, 49 -52 .

Jayaraman, N., S. Suresh, and N. M. Nirmala Ganeshan, 1997: Genetic enhancement and breeding strategies in small millets. In: National Seminar on Small Millets: Current Research Trends and Future Priorities as Food Feed and in Processing for Value Addition, 19-21. 2324 April, 1997, Bangalore, India, (Extended summaries).

Kajuna, S. T. A. R., 2001: MILLET: Post-harvest Operations. Available at: http://www.fao.org/fileadmin/user_upload/inpho/docs/Post_Harvest_Compendium_-_MILLET.pdf (last accessed on July 21, 2014).

Kanak, A. R., M. J. Khan, M. R. Debi, Z. H. Khandakar, and M. K. Pikar, 2013: Comparison on biomass production of three fodder germplasms. Bang. J. Anim. Sci. 42, 35-39.

Kim, J. Y., K. C. Jang, B. R. Park, S. I. Han, K. J. Choi, S. Y. Kim, S. H. Oh, J. E. Ra, T. J. Ha, J. H. Lee, J. Hwang, H. W. Kang, and W. D. Seo, 2011: Physicochemical and antioxidative properties of selected barnyard millet (Echinochloa utilis) species in Korea. Food Sci. Biotechnol. 20, 461-469.

Kono, Y., A. Yamauchi, N. Kawamura, and J. Tatsumi, 1987: Interspecific differences of the capacities of water-logging and drought tolerances among summer cereals. Jpn J Crop Sci 56, 115-129.

Krishna Kumari, S., and B. Thayumanavan, 1998: Characterization of starches of proso, foxtail, barnyard, kodo, and little millets. Plant Foods Hum. Nutr. 53, 47-56.

Kulkarni, L. R., R. K. Naik, and P. A. Katarki, 1992: Chemical composition of minor millets. Karnataka J. Agric. Sci. 5, 255-258. 
Kumagai, S., H. Matusda, H. Yoshida, A. Abe, S. Sagawa, and T. Hoshino, 2011: Optimum harvest time judged from maturation properties of Japanese Barnyard millet in the late ripening stage. Jpn J Crop Sci 80, $29-34$

Kumari, K., M. Muthamilarasan, G. Misra, S. Gupta, A. Subramanian, S. K. Parida, D. Chattopadhyay, and M. Prasad, 2013: Development of eSSR-Markers in Setaria italica and their applicability in studying genetic diversity, cross-transferability and comparative mapping in Millet and non-Millet species. PLoS ONE 8, e67742.

Lata, C., S. Gupta, and M. Prasad, 2013: Foxtail millet: a model crop for genetic and genomic studies in bioenergy grasses. Critical Reviews in Biotechnology 33 (3), 328-343.

Li, P., and T. P. Brutnell, 2011: Setaria viridis and Setaria italica, model genetic systems for the Panicoid grasses. J. Exp. Bot. 62, 3031-3037

Lohani, U. C., J. P. Pandey, and N. C. Shahi, 2012: Effect of degree of polishing on milling characteristics and proximate compositions of barnyard millet (Echinochloa frumentacea). Food Bioprocess Technol. 5 (3), 1113-1119. Doi:10.1007/s11947-011-0518-6.

Lorenz, K., 1983: Tannin and phytate content of Proso Millets (Panicum miliaceum). Cereal Chem. 60, 424-426.

Maikhuri, R. K., K. S. Rao, and R. S. Semwal, 2001: Changing scenario of Himalayan agro-ecosystem: loss of agro-biodiversity an indicator of environment change in Central Himalaya, India. Environmentalist 21, $23-29$.

Majid, M. A., M. A. Hamid, and Mannujan, 1989: Importance, genetic resources and breeding of small millets in Bangladesh. In: A. Seetharam, K.W. Riley, and G. Harinarayana, (eds), Small Millets in Global Agriculture, 71-76. Oxford \& IBH Publishing Co, New Delhi.

Mandelbaum, C. I., W. E. Barbeau, and K. W. Hilu, 1995: Protein, calcium, and iron content of wild and cultivated species of Echinochloa. Plant Foods Hum. Nutr. 47, 101-108.

Manidool, C., 1992: Echinochloa crus-galli (L.) P. Beauv. In: L. t' Mannetje, and R.M. Jones (eds), Plant Resources of South-east Asia. No.4 Forages, 303. Pudoc Scientific Publishers, Wageningen, the Netherlands.

Maun, M. A., and S. C. Barrett, 1986: The biology of Canadian weeds 77. Echinochloa crus- galli (L.) Beauv. Can. J. Plant Sci. 66, 739759.

Mehra, H. S., H. C. Joshi, and J. Chikara, 1985: Induced mutations in Japanese millet. Indian J. Agric. Sci. 55, 294-295.

Mehta, H., P. C. Tyagi, and K. P. Mohapatra, 2005: Genetic diversity in Barnyard millet (Echinochloa frumentacea Roxb.) Indian. Indian J. Genet. 65, 293-295.

Mehta, H., P. C. Tyagi, and K. P. Mohapatra, 2007: Genetic divergence in relation to morphophysiological traits in Barnyard millet. Crop Improv. 34, 86-89.

Michael, P., 1994: Distribution and taxonomy of Echinochloa - a world view with a key to the species occurring in China. Proceedings of the 5th Weed Science Conference of China (Kunming, China, 25-30 November 1994), 161-166. Weed Science Society of China, Kunming, China.

Michael, P., 2001: The taxonomy and distribution of Echinochloa species (barnyard grasses) in the Asian-Pacific region, with a review of pertinent biological studies. In: Proceedings of the 18th APWSS Conference (Beijing, China, 28 May-2 June 2001), 57-66. Standard Press of China, Beijing.

Migo, T. R., R. R. Pamplona, M. Dingkuhn, and S. K. DeDatta, 1991 Interaction of water stress and nitrogen supply on the photosynthetic parameters of two upland rices and two upland weeds. Philipp. J. Weed Sci. 18, 69-89.

Mitchell, W. A., 1989: Japanese Millet (Echinochloa crus-galli var. frumentacea). Technical Report EL-89-13, 8. Environment Laboratory, Department of the Army, Waterways Experiment Station, 3909 Halls Ferry Road, Mississippi.

Mitich, L. W., 1990: Intriguing world of weeds. Barnyardgrass. Weed Technol. 4, 918-920.

Monteiro, P. V., L. Sudharshana, and G. Ramachandra, 1987: Japanese barnyard millet (Echinochloa frumentacea): protein content, quality and SDS-PAGE of protein fractions. J. Sci. Food Agric. 43, 17-25.
Moriwaki, J., and T. Tsukiboshi, 2009: Colletotrichum echinochloae, a new species on Japanese barnyard millet (Echinochloa utilis). Mycoscience 50, 273-280.

Muldoon, D. K., 1985: The effect of photoperiod on the growth and development of Echinochloa spp. Millets. Aust. J. Exp. Agric. 25, $428-433$.

Muldoon, D. K., C. J. Perason, and J. L. Wheleer, 1982: The effect of temperature on growth and development of Echinochloa millets. Ann. Bot. 50, 665-672.

Muthamilarasan, M., B. Venkata Suresh, G. Pandey, K. Kumari, S. K. Parida, and M. Prasad, 2014: Development of 5123 Intron-Length Polymorphic markers for large-scale genotyping applications in Foxtail millet. DNA Res. 21, 41-52.

Nagaraja, A., and S. G. Mantur, 2008: Evaluation of barnyard millet entries for grain smut resistance and yield. Mysore J. Agric. Sci. 42, $375-377$.

Nagaraja, A., J. Kumar, A. K. Jain, Y. Narasimhudu, T. Raghuchander, B. Kumar, and B. Hanumanthe Gowda, 2007: Compendium of Small Millets Diseases, 80pp. All India Coordinated Small Millets Improvement Project, GKVK, Bangalore.

Napper, D. M., 1965: Grasses of Tanganyaika: With Keys for Identification, Bulletin 18, 146 pp. Ministry of Agriculture Forest and Widlife, Tanzania.

National Research Council, 1996: Lost crops of Africa vol. I: grains. Board on Science and Technology for International Development. National Academy Press, Washington, D.C.

Nesbitt, M., 2005: Grains. In: Sir Ghillean Prance, and Mark Nesbitt (eds), The Cultural History of Plants, 57/435. Routledge Publishers, New York, USA.

Nirmalakumari, A., and M. Vetriventhan, 2009: Phenotypic analysis of anther and pollen in diversified genotype of barnyard millet (Echinochloa frumentacea) floral characters. ICFAI Univ. J. Genet. Evol. 2, $12-16$.

Nozawa, S., H. Nakai, and Y. I. Sato, 2004: Characterization of microsatellite and ISSR polymorphisms among Echinochloa (L.) Beauv. spp. in Japan. Breed. Res. 6, 87-93.

Nozawa, S., M. Takahashi, H. Nakai, and Y. I. Sato, 2006: Differences in SSR variations between Japanese barnyard millet (Echinochloa esculenta) and its wild relative E. crus-galli. Breed. Sci. 56, 335-340.

Obara, T., 1936: On the nutritive value of Japanese barnyard millet. J. Agric. Chem. Soc. Japan 12, 1049-1058.

Obara, T., 1938: Studies of barnyard millet. I. Classification of varieties by agricultural traits. Jpn J. Crop. Sci. 9, 471-518.

Padulosi, S., B. Mal, S. Bala Ravi, J. Gowda, K. T. K. Gowda, G. Shanthakumar, N. Yenagi, and M. Dutta, 2009: Food security and climate change: role of plant genetic resources of minor millets. Indian J. Plant. Genet. Resour. 22, $1-16$.

Pandey, G., G. Mishra, K. Kumari, S. Gupta, S. K. Parida, D. Chattopadhyay, and M. Prasad, 2013: Genome-wide development and use of microsatellite markers for large-scale genotyping applications in Foxtail millet [Setaria italica (L.)]. DNA Res. 20, 197-207.

Pawar, C. P., R. K. Rathod, P. A. Navale, and G. Harinarayana, 1982: Natural incidence of grain Smut in sawa Echinochloa-Frumentacea. Curr. Sci. 51, 480.

Poncet, V., F. Lamy, J. Enjalber, H. Joly, A. Sarr, and T. Robert, 1998: Genetic analysis of domestication syndrome in pearl millet (Pennisetum glaucum L., Poaceae); inheritance of the major characters. Heredity 81, 648-658.

Poncet, V., F. Lamy, K. M. Devos, M. G. Gale, A. Sarr, and T. Robert, 2000: Genetic control of domestication traits in pearl millet (Pennisetum glaucum L., Poaceae). Theor. Appl. Genet. 100, 149-159.

Poongodi, T., J. B. M. Vijayakumar, P. Nazni, and M. Rajeshwari, 2003: Value addition for minor millets and its glycemic load among normal and type 2 diabetic subjects. Paper presented at the 39th national Nutritional Conference of NSI, Hyderabad.

Potvin, C., 1986: Biomass allocation and phenological differences among southern and northern populations of the C4 grass Echinochloa crusgalli. J. Ecol. 74, 915-923. 
Potvin, C., 1991: Temperature-induced variation in reproductive success field and control experiments with the $\mathrm{C} 4$ grass Echinochloa crus-galli. Can. J. Bot. 69, 1577-1582.

Prabha, D., Y. K. Negi, and V. K. Khanna, 2010: Morphological and isozyme diversity in the accessions of two cultivated species of barnyard millet. Nat. Sci. 8, 71-76.

Rahn, E. M., R. D. Sweet, J. Vengris, and S. Dunn, 1968: Life history studies as related to weed control in the Northeast. 5. Barnyardgrass. University of Delaware, Agricultural Research Station, Bulletin 368, $1-46$.

Rout, G. R., S. Samantaray, and P. Das, 1997: Regeneration of a metal tolerant grass Echinochloa colona via somatic embryogenesis from suspension cultures. Biol. Plant. 40, 17-23.

Ruiz-Santaella, J. P., F. Bastida, A. R. Franco, and R. D. Prado, 2006: Morphological and molecular characterization of different Echinochloa spp. and Oryza sativa populations. J. Agric. Food Chem. 54, 11661172.

Samantaray, S., G. R. Rout, and P. Das, 1995: In vitro plant regeneration from leaf base and mesocotyl cultures of Echinochloa colona. Plant Cell Tiss. Org. Cult. 40, 37-41.

Samantaray, S., G. R. Rout, and P. Das, 1996: Regeneration of plants via somatic embryogenesis from leaf base and leaf tip segments of Echinochloa colona. Plant Cell Tiss. Org. Cult. 47, 119125 .

Samantaray, S., G. R. Rout, and P. Das, 2001: Induction, selection and characterization of $\mathrm{Cr}$ and Ni-tolerant cell lines of Echinochloa colona (L.) Link in vitro. J. Plant Physiol. 158, 1281-1290.

Sankhla, A., T. D. Davis, D. Sankhla, A. Upadhyay, and S. Joshi, 1992: Influence of growth regulators on somatic embryogenesis, plant regeneration and post-transplant survival of Echinochloa frumentacea. Plant Cell Rep. 11, 368-371.

Schlegel, R. H. J., 2010: Dictionary of Plant Breeding, 2nd edn, 422. CRC Press, Taylor and Francis Group, Boca Raton - London - New York.

Seetharam, A., J. Gowda, and J. H. Halaswamy, 2003: Small millets. In: S. K. Chowdhury, and S. K. Lal (eds), Nucleus and Breeder Seed Production Manual, 54-67. Indian Agricultural Research Institute, New Delhi, India.

Singh, H. S., and K. Singh, 2005: Status and needs of pasture and fodder management in Uttaranchal. In: J. K. Bisht, and A. K. Srivastava (eds), Road Map for Pasture and Fodder Development in NWHR for Livestock Sustenance, 39-64. Vivekananda Parvatiya Krishi Anusandhan Sansthan (Indian Council of Agriculture Research), Almora, Uttarakhand, India.

Singh, K. P., S. Kundu, and H. S. Gupta, 2003: Development of higher capacity thresher for ragi/kodo. In: Recent Trend in Millet Processing and Utilization, 109-116. CCSHAU, Hissar, India.

Sood, S., R. K. Khulbe, N. Saini, A. Gupta, and P. K. Agrawal, 2014: Interspecific hybrid between Echinochloa esculenta (Japanese barnyard millet) and E. frumentacea (Indian barnyard millet) - a new avenue for genetic enhancement of barnyard millet. Elect. J. Plant Breed. 5, $248-253$.

Sundararaj, D. P., and G. Thulasidas, 1976: Botany of Field Crops. Macmillan Publisher, New Delhi, India, 509 pp.

Sung, S. S., G. R. Leather, and M. G. Hale, 1987: Development and germination of barnyard grass (Echinochloa crus-galli) seeds. Weed Sci. 35, $211-215$.

Surekha, N., 2004: Fabrication of barnyard millet health mix: Clinical and shelf life evaluation. MHSc, Thesis, Univ. Agric. Sci., Dharwad.

Takase, K., 2009: Prehistoric and Protohistoric Plant Use in the Japanese Archipelago. Meiji University Premodern Japan Research Exchange, 0708 DEC 2009, USC, Tokyo, Japan.

Talwar, M., and A. Rashid, 1989: Somatic embryo formation from unemerged inflorescences and immature embryos of a graminaceous crop Echinochloa. Ann. Bot. 64, 195.

Tomita, Y., Y. Sugimoto, S. Sakamoto, and H. Fuwa, 1981: Some properties of starches of grain amaranth and several millets. J. Nutr. Sci. Vitaminol. 27, 471-484.
Tyagi, A. K., S. Bharal, A. Rashid, and N. Maheshwari, 1985: Plant regeneration from tissue cultures initiated from immature inflorescences of a grass Echinochloa colona (L.) Link. Plant Cell Rep. 4, 115117.

Ugare, R., 2008: Health benefits, storage quality and value addition of barnyard millet (Echinochloa frumentacaea Link). M. Sc. Thesis, Department of Food Science and Nutrition, College of Rural Home Science, University of Agricultural Sciences, Dharwad.

Ugare, R., B. Chimmad, R. Naik, P. Bharati, and S. Itagi, 2014: Glycemic index and significance of barnyard millet (Echinochloa frumentacae) in type II diabetics. J. Food Sci. Technol. 51, 392395.

Upadhyaya, H. D., C. L. L. Gowda, and D. V. S. S. R. Sastry, 2008: Plant genetic resources management: collection, characterization, conservation and utilization. J. SAT Agric. Res. 6, 1-15.

Upadhyaya, H. D., S. L. Dwivedi, S. K. Singh, S. Singh, M. Vetriventhan, and S. Sharma, 2014: Forming core collections in Barnyard, Kodo, and Little Millets using morphoagronomic descriptors. Crop Sci. 54, 2673-2682.

Veena, B., B. V. Chimmad, R. K. Naik, and G. Shantakumar, 2004: Development of barnyard millet based traditional foods. Karnataka J. Agric. Sci. 17, 522-527.

Veena, S., V. C. Bharati, K. N. Rama, and G. Shanthakumar, 2005: Physico-chemical and nutritional studies in barnyard millet. Karnataka J. Agric. Sci. 18, 101-105.

Venkata Suresh, B., M. Muthamilarasan, G. Misra, and M. Prasad, 2013: FmMDb: a versatile database of foxtail millet markers for millets and bioenergy grasses research. PLoS ONE 8, e71418.

Watanabe, N., 1970: A spodographic analysis of millet from prehistoric Japan. J. Fac. Sci. Univ. Tokyo, Sect 3, 357-379.

Watanabe, M., 1999: Antioxidative phenolic compounds from Japanese barnyard millet (Echinochloa utilis) grains. J. Agric. Food Chem. 47, $4500-4505$.

Yabuno, T., 1962: Cytotaxonomic studies on the two cultivated species and the wild relatives in the genus Echinochloa. Cytologia 27, 296305.

Yabuno, T., 1966: Biosystematic study of the genus Echinochloa. J. Jap. Bot. 19, 277-323.

Yabuno, T., 1971: A note on barnyard millet. SABRAO Newslett. 3, $43-45$.

Yabuno, T., 1975: The classification and geographical distribution of the genus Echinochloa. Weed Res. 20, 97-104.

Yabuno, T., 1984: A biosystematic study on Echinochloa oryzoides (Ard.) Fritsch. Cytologia 49, 673-678.

Yabuno, T., 1987: Japanese barnyard millet (Echinochloa utilis, Poaceae) in Japan. Econ. Bot. 41, 484-493.

Yabuno, T., 1996: Taxonomy and phylogeny of the genus Echinochloa. In: Yabuno T., and H. Yamaguchi (eds), Natural History of Genus Echinochloa, 16-28. Daw Elanco/Dow Chemical Company, Tokyo (in Japanese).

Yabuno, T., 2001: Taxonomy and phylogeny of the genus Echinochloa. In: T. Yabuno, and H. Yamaguchi (eds), Natural History of Genus Echinochloa, 15-30. Zennokyo Shuppan, Tokyo (in Japanese).

Yadav, R., and V. K. Yadav, 2013: Comparative performance of Indian and Japanese barnyard millet cultivars under varied fertility conditions for dual use in Indian Central Himalaya. Range Manag. Agroforest. 34, 175-178.

Yadav, C. B., M. Muthamilarasan, G. Pandey, Y. Khan, and M. Prasad, 2014: Development of novel microRNA-based genetic markers in foxtail millet for genotyping applications in related grass species. Mol. Breed. Doi:10.1007/s11032-014-0137-9.

Yamaguchi, H., S. Umemoto, and Y. Masanaga, 1996: Studies on barnyard grasses, especially on the non-shattering form of Echinchloa oryzicola Vasing [in Yungui plateau, China]. Weed Res Japan 41, 111115 (in Japanese).

Yamaguchi, H., A. Utano, K. Yasuda, A. Yano, and A. Soejima, 2005: A molecular phylogeny of wild and cultivated Echinochloa in East Asia inferred from non-coding region sequences of trnT-L-F. Weed Biol. Manag. 5, 210-218. 
Yasuda, K., A. Yano, Y. Nakayama, and H. Yamaguchi, 2002: Molecular identification of Echinochloa oryzicola and E. crus-galli using a polymerase chain reaction-restriction fragment length polymorphism technique. Weed Biol. Manag. 2, 11-17.
Yuichiro, M., U. Shinya, and H. Yamaguchi, 1999: Identification of polyploid groups in the genus Echinochloa by isozyme analysis. J. Weed Sci. Technol. 44, 205-217. 